JURNAL SYNTAX FUSION

Vol 1 No 12, Desember 2021

E-ISSN: 2775-6440 | P-ISSN: 2808-7208

Jurnal Homepage https://fusion.rifainstitute.com

\title{
HUBUNGAN ANTARA UMUR, JENIS KELAMIN, INDEKS MASSA TUBUH, LAMA LATIHAN DENGAN DAYA LEDAK OTOT TUNGKAI PADA ATLET TAEKWONDO
}

\author{
Atik Handariati, Galih Aji Gandika \\ Universitas Negeri Sebelas Maret, Akademi Fisioterapi RS Dustira \\ Email: atikhanda14@gmail.com
}

\begin{abstract}
Abstrak
Taekwondo merupakan olahraga bela diri yang mengandalkan tendangan. Bagi seorang atlet taekwondo untuk melakukan tendangan perlu ditunjang dengan daya ledak otot tungkai. Penelitian ini bertujuan untuk menganalisis hubungan umur, jenis kelamin, indeks massa tubuh, lama latihan dengan daya ledak otot tungkai pada atlet taekwondo. Penelitian deskriptif analitik ini menggunakan desain cross sectional. Subjek penelitian adalah anggota taekwondo di GOR Sangkuriang dan GOR Lions kota Cimahi provinsi Jawa Barat berjumlah 95 orang. Variabel dependen adalah daya ledak otot tungkai. Variabel independen adalah umur, jenis kelamin, indeks massa tubuh dan lama latihan. Instrumen yang digunakan adalah kuesioner dan alat ukur vertical jump. Data dianalisis bivariat dengan menggunakan OR dan uji chi square. Daya ledak tungkai meningkat dengan bertambahnya umur $(\mathrm{OR}=2.89 ; \mathrm{CI} 95 \%=1.23$ hingga $5.77 ; \mathrm{p}=0.010)$ dan lama latihan $(\mathrm{OR}=7.44$; CI 95\%= 2.96 hingga 18.67; $\mathrm{p}<0.001)$. Daya ledak tungkai menurun dengan Indeks massa tubuh namun secara statistik tidak signifikan (OR= 0.72 ; CI $95 \%=0.30$ hingga $1.18 ; \mathrm{p}=0.600$ ). Jenis kelamin meningkatkan daya ledak tungkai, namun secara statistik tidak signifikan $(\mathrm{OR}=1.14$; CI 95\%=0.51 hingga 2.56; $\mathrm{p}=0.90$ ). Daya ledak tungkai meningkat dengan umur dan lama latihan. Hubungan daya ledak tungkai dengan jenis kelamin dan indeks massa tubuh secara statistik tidak signifikan.
\end{abstract}

Kata Kunci: daya ledak tungkai, indeks massa tubuh, latihan

\section{Abstract}

Taekwondo is a martial sport that relies on kicks. For a taekwondo athlete to kick, it is necessary to support the explosive power of the leg muscles. This study aims to analyze the relationship between age, sex, body mass index, length of exercise with leg muscle explosive power in taekwondo athletes. Subjects and Methods: This analytic descriptive study used a cross sectional design. The subjects of the study were taekwondo members at Sangkuriang Sports Hall and Lions Gymnasium in Cimahi City, West Java Province, totaling 95 people. The dependent variable is leg muscle explosive power. The independent variables were age, gender, body mass index and duration of exercise. The instruments used are questionnaires and vertical jump measuring instruments. Data were analyzed bivariately using OR and chi square test. The explosive power of the limbs 
increased with increasing age $(O R=2.89 ; 95 \% C I=1.23$ to $5.77 ; p=0.010)$ and duration of exercise $(O R=7.44 ; 95 \% C I=2.96$ to 18.67; $p<0.001)$. Leg explosive power decreased with body mass index but not statistically significant $(O R=0.72$; 95\% CI=0.30 to 1.18; $p=0.600)$. Gender increased limb explosive power, but not statistically significant $(O R=1.14 ; 95 \% C I=0.51$ to $2.56 ; p=0.900)$. The explosive power of the limbs increases with age and duration of exercise. The relationship between limb explosive power and sex and body mass index was not statistically significant.

Keywords: limb explosive power, body mass index, exercise

Diterima: 12-11-2021Ｄirevisi: 12-12-2021Ｄiterbitkan: 20-12-2021

\section{Pendahuluan}

Taekwondo adalah suatu cabang olahraga modern yang berakar pada bela diri tradisional Korea dan mulai dikenal sejak tahun 1954, seiring dengan semakin populernya olahraga beladiri, taekwondo mulai dikenal diseluruh dunia termasuk salah satu nya di Indonesia. Taekwondo terdiri dari 3 kata dasar, yaitu : tae yang artinya menghancurkan dengan menggunakan kaki, kwon yang artinya menghancurkan dengan menggunakan tangan, do yang artinya seni, sehingga dapat diartkan bahwa Taekwondo ialah seni beladiri yang terdiri dari teknik tendangan dan pukulan (Harun and Xiong, 2010)

Terdapat keunikan dalam olahraga beladiri Taekwondo dimana Teknik tendangan lebih dominan dibanding dengan pukulan atau bantingan, sehingga taekwondo sering juga disebut dengan "Seni Beladiri Menendang". Taekwondo memiliki banyak variasi tendangan seperti ap chagi, dollyo chagi, narae chagi, dwi chagi, dwi hurigi, yeop chagi, dan mireo chagi. Dalam suatu pertandingan taekwondo untuk menentukan kemenangan ditentukan oleh banyaknya poin yang didapat, terdapat 2 area sasaran yaitu bagian eolgul (wajah) bagian momtong (batang tubuh atau perut dan dada) dimana area tersebut memiliki penilaian poin yang berbeda sesuai dengan area sasaran dan teknik tendangan yang digunakan saat menyerang (PBTI, 2018)

Daya ledak otot (power otot) merupakan suatu rangkaian kerja dari beberapa unsur gerak otot/kombinasi dari tenaga eksplosif, kekuatan yang dilepaskan secara maksimum dengan kecepatan maksimum. Daya ledak otot tungkai adalah kemampuan otot untuk mengarahkan kekuatan dalam waktu yang sangat singkat untuk memberikan objek momentum yang paling baik pada tubuh atau objek dalam suatu gerakan explosive yang utuh guna untuk mencapai tujuan yang dikehendaki (Wahyuni and Donie, 2020)

Daya ledak otot merupakan faktor fundamental dalam melompat, melempar, memukul dan menendang (Pasaribu, 2015). Daya ledak otot meliputi otot bagian ekstremitas bawah dan ekstremitas atas. Pada ekstremitas bawah, otot yang lebih banyak bekerja adalah kelompok otot $\mathrm{m}$ gastrocnemius dan kelompok otot $\mathrm{m}$. quadriceps femoris. Tes yang dapat digunakan untuk mengetahui daya ledak otot tungkai adalah dengan vertical jump (Baihaqi and Hariyanto, 2020)

Menurut Penelitian epidemiologi terbaru menunjukkan bahwa anak laki-laki lebih menyukai olahraga tim dan olahraga kontak dibandingkan anak perempuan. Anak laki- 
laki mengalami cedera dua kali lebih banyak dibandingkan anak perempuan. Anak lakilaki lebih sering mengalami cedera yang bersifat traumatis, anak perempuan lebih sering mengalami cedera yang diakibatkan kegiatan olahraga yang berlebihan (overuse). Perbedaan faktor resiko dan jenis cedera ini berhubungan dengan pola gerakan olah raga yang dilakukan, kekuatan otot yang berbeda serta pemilihan jenis cabang olahraga (Ismunandar, 2020)

IMT merupakan salah satu pengukuran anthopometri yang digunakan untuk penilaian status gizi atau menentukan standar proporsi komposisi tubuh pada orang dewasa, remaja hingga anak-anak, dengan membandingkan berat badan dan tinggi badan (Baihaqi and Hariyanto, 2020). IMT yang bagus diperlukan untuk menghasilkan gerakan yang cepat dan maksimal. IMT dapat menjadi salah satu faktor risiko terjadinya cedera khususnya pada ligamen dikarenakan apabila seorang atlet memiliki IMT berlebih akan membuat tekanan pada ligamen betambah besar dan akan meningkatkan resiko cedera, dibandingkan dengan orang yang memiliki tinggi dan berat badan yang ideal. Obesitas juga dapat memperburuk kondisi sendi dan menyebabkan penurunan jaringan otot yang signifikan (Wiranata, Handoyo and Kurniawan, 2020).

Latihan atau exercise adalah subkelompok aktifitas fisik berupa gerakan tubuh yang terencana, terstruktur dan repetitive (berulang). Latihan adalah proses melakukan kegiatan olahraga yang telah direncanakan secara sistematis dan terstruktur dalam jangka waktu yang lama untuk meningkatkan kemampuan gerak baik dari segi fisik, teknik, taktik, dan mental untuk menunjang keberhasilan siswa atau atlet dalam memperoleh prestasi olahraga yang maksimal (Langga and Supriyadi, 2017). Semakin lama seorang atlet mengikuti program latihan taekwondo maka akan semaikn baik pula kualitas ototnya yang berpengaruh terhadap daya ledak ototnya. Semakin terlatihnya atlet maka akan membuat otot menjadi fleksibel dan meminimalisir terjadinya cedera karena semakin fleksibel otot seseorang maka semakin kecil kemungkinan orang tersebut untuk cedera (Widhinata, 2010)

\section{Metode Penelitian}

Penelitian deskriptif analitik ini menggunakan desain cross sectional. Subjek penelitian adalah anggota taekwondo di GOR Sangkuriang dan GOR Lions kota Cimahi provinsi Jawa Barat berjumlah 95 orang. Penelitian dilakukan pada bulan Februari 2021 sampai dengan Juni 2021, dengan waktu pengumpulan data selama 3 minggu pada tanggal 25 April sd 17 Mei 2021. Variabel dependen adalah daya ledak otot tungkai. Variabel independen adalah umur, jenis kelamin, indeks massa tubuh dan lama latihan. Instrumen yang digunakan adalah kuesioner dan alat ukur vertical jump. Data dianalisis bivariat dengan menggunakan OR dan uji chi square. Penelitian ini telah mendapatkan persetujuan etik dari Komisi Etik Poltekkes Kemenkes Jakarta III dengan nomor surat KEPK-PKJ3/020/VI/2021 


\section{Hasil}

\section{Gambaran Karakteristik Subjek Penelitian}

Analisis bivariat menunjukkan karakteristik subjek penelitian ini meliputi, umur, jeniskelamin, indeks massa tubuh, lama latihan dan daya ledak tungkai.

Tabel 1

Distribusi Frekuensi Karakteristik Subjek Penelitian

\begin{tabular}{lll}
\hline \multirow{2}{*}{ Variabel } & \multicolumn{2}{l}{ Jumlah } \\
\cline { 2 - 3 } Umur & $\mathbf{~}$ & \% \\
12-16 tahun & 55 & 57,9 \\
17-19 tahun & 40 & 100 \\
\hline Jenis Kelamin & & \\
Laki-laki & 49 & 51,6 \\
Perempuan & 46 & 48,4 \\
\hline IMT & & \\
Kurus & 5 & 5,3 \\
Normal & 64 & 67,4 \\
Gemuk & 26 & 27,4 \\
\hline Lama Latihan & & \\
1-5 tahun & 51 & 53,7 \\
$>$ 6 tahun & 44 & 46,3 \\
\hline Daya Ledak Tungkai & & \\
Luar biasa & 4 & 4,2 \\
Sangat Baik & 14 & 14,7 \\
Diatas rata-rata & 32 & 33,7 \\
Normal & 45 & 47,4 \\
\hline
\end{tabular}

Mayoritas berjenis kelamin laki-laki yaitu sebanyak 49 orang $(51,6 \%)$, sedangkan berdasarkan umur responden, mayoritas atlet berumur 12-16 tahun yaitu sebanyak 55 orang $(57,9 \%)$. Tabel 1 juga menunjukkan bahwa mayoritas responden baru menjalani latihan taekwondo 1-5 tahun yaitu sebanyak 51 orang $(53,7 \%)$ dan mayoritas responden memiliki daya ledak tungkai dalam kategori normal yaitu sebanyak 45 orang $(47,4 \%)$

\section{Hubungan Umur dengan Daya ledak Tungkai}

Tabel 2

Hubungan Umur dengan daya ledak tungkai

Daya Ledak Tungkai Jumlah


Hubungan Antara Umur, Jenis Kelamin, Indeks Massa Tubuh, Lama Latihan Dengan Daya Ledak Otot Tungkai Pada Atlet Taekwondo

\begin{tabular}{|c|c|c|c|c|c|c|c|c|}
\hline \multirow[t]{2}{*}{ Umur } & \multicolumn{2}{|c|}{ Normal } & \multicolumn{2}{|c|}{$\begin{array}{l}\text { Di atas rata- } \\
\text { rata }\end{array}$} & & & \multirow{2}{*}{$\begin{array}{l}P \\
\text { Valu } \\
e \\
\end{array}$} & \multirow{2}{*}{$\begin{array}{l}O R \\
C I)\end{array}$} \\
\hline & $\mathrm{n}$ & $\%$ & $\mathrm{n}$ & $\%$ & $\mathrm{n}$ & $\%$ & & \\
\hline 12-16 tahun & 32 & 58,2 & 23 & 41,8 & 55 & 100 & \multirow{3}{*}{$\begin{array}{l}0,02 \\
3\end{array}$} & \multirow{3}{*}{$\begin{array}{l}2,890 \\
(1,233- \\
5,770)\end{array}$} \\
\hline 17-19 tahun & 13 & 32,5 & 27 & 67,5 & 40 & 100 & & \\
\hline Total & 45 & 100 & 50 & 100 & 95 & 100 & & \\
\hline
\end{tabular}

Tabel 2 menjelaskan bahwa dari 55 responden yang berumur 12-16 tahun sebanyak $58,2 \%$ memiliki daya ledak tungkai normal dan sebanyak 41,8\% memiliki daya ledak tungkai di atas rata-rata, tabel 4 juga menjelaskan bahwa dari 40 responden yang berumur 17-19 tahun sebanyak 67,5\% memiliki daya ledak tungkai diatas rata-rata dan sebanyak $32,5 \%$ responden memiliki daya ledak tungkai normal. Hasil uji statistik chi-square disimpulkan bahwa ada hubungan antara umur terhadap daya ledak tungkai atlet taekwondo Kota Cimahi dengan hasil nilai pvalue $=0,014<\alpha(\alpha=0,05)$. Dari hasil uji statistik diperoleh nilai $\mathrm{OR}=2,890$ dan nilai $95 \% \mathrm{Cl}=1,233-5,770$, yang berarti kelompok usia 17-19 memiliki kecerendungan resiko daya ledak otot tungkai di atas ratarata 2,890 lebih besar.

\section{Hubungan Jenis Kelamin dengan Daya Ledak Tungkai}

Tabel 3

Hubungan Jenis Kelamin dengan Daya Ledak Tungkai

\begin{tabular}{|c|c|c|c|c|c|c|c|c|}
\hline \multirow{3}{*}{$\begin{array}{l}\text { Jenis } \\
\text { Kelamin }\end{array}$} & \multicolumn{6}{|c|}{ Daya Ledak Tungkai } & \multirow{3}{*}{$\begin{array}{l}P \\
\text { Valu } \\
e\end{array}$} & \multirow{3}{*}{$\begin{array}{l}\text { OR } \\
C I)\end{array}$} \\
\hline & \multicolumn{2}{|c|}{ Normal } & \multicolumn{2}{|c|}{$\begin{array}{l}\text { Di atas rata- } \\
\text { rata }\end{array}$} & \multicolumn{2}{|c|}{ Jumlah } & & \\
\hline & $\mathrm{n}$ & $\%$ & $\mathrm{n}$ & $\%$ & $\mathrm{n}$ & $\%$ & & \\
\hline Laki-laki & 24 & 49 & 25 & 51 & 49 & 100 & \multirow{3}{*}{$\begin{array}{l}0,90 \\
5\end{array}$} & \multirow{3}{*}{$\begin{array}{l}1,143 \\
(0,510- \\
2,560)\end{array}$} \\
\hline Perempuan & 21 & 45,7 & 25 & 54,3 & 46 & 100 & & \\
\hline Total & 45 & 100 & 50 & 100 & 95 & 100 & & \\
\hline
\end{tabular}

Tabel 3 menjelaskan bahwa dari 49 responden berjenis kelamin laki-laki sebanyak 49\% memiliki daya ledak tungkai normal dan 6,1\% memiliki daya ledak tungkai di atas rata-rata, tabel 4.3 juga menunjukkan bahwa dari 46 responden yang berjenis kelamin perempuan sebanyak $54,3 \%$ responden memiliki daya ledak tungkai di atas rata-rata dan 45,7\% memiliki daya ledak tungkai normal.

Hasil uji statistik chi square disimpulkan bahwa tidak ada hubungan antara jenis kelamin terhadap daya ledak tungkai atlet taekwondo Kota Cimahi dengan hasil nilai pvalue $=0,905>\alpha(\alpha=0,05)$. Dari hasil uji statistik diperoleh pula nilai $\mathrm{OR}=1,143$ dan nilai $95 \% \mathrm{Cl}=0,510-2,560$. 


\section{Hubungan Indeks Massa Tubuh dengan Daya ledak Tungkai}

Tabel 4

Hubungan Indeks Massa Tubuh dengan Daya Ledak Tungkai

\begin{tabular}{|c|c|c|c|c|c|c|c|c|}
\hline \multirow{3}{*}{ IMT } & \multicolumn{6}{|c|}{ Daya Ledak Tungkai } & \multirow{3}{*}{$P$ Value } & \multirow{3}{*}{ OR $(95 \% C I)$} \\
\hline & \multicolumn{2}{|c|}{ Normal } & \multicolumn{2}{|c|}{$\begin{array}{l}\text { Di atas rata- } \\
\text { rata }\end{array}$} & \multicolumn{2}{|c|}{ Jumlah } & & \\
\hline & $\mathrm{n}$ & $\%$ & $\mathrm{n}$ & $\%$ & $\mathrm{n}$ & $\%$ & & \\
\hline Tidak Normal & 13 & 41,9 & 18 & 58,1 & 31 & 100 & & \\
\hline Normal & 32 & 50 & 32 & 50 & 64 & 100 & 0,604 & $0,722 \quad(0,304-$ \\
\hline Total & 45 & 100 & 50 & 100 & 95 & 100 & & \\
\hline
\end{tabular}

Tabel 4.2 dapat dijelaskan bahwa pada 31 responden yang memiliki IMT tidak normal sebanyak 41,9\% memiliki daya ledak tungkai normal dan 58,1\% memiliki daya ledak tungkai yang luar biasa. Tabel 3.2 juga menunjukkan bahwa dari 64 responden yang memiliki IMT normal sebanyak 50\% memiliki daya ledak tungkai normal dan 50\% responden memiliki daya ledak tungkai yang luar biasa.

Hasil uji statistik chi square disimpulkan bahwa tidak ada hubungan antara IMT terhadap daya ledak tungkai atlet taekwondo Kota Cimahi dengan hasil nilai pvalue $=$ $0,604>\alpha(\alpha=0,05)$. Dari hasil uji statistik diperoleh pula nilai $\mathrm{OR}=0,722$ dan nilai $95 \%$ $\mathrm{Cl}=0,304-1,176$.

\section{Hubungan Lama Latihan dengan Daya Ledak Tungkai}

\section{Tabel 5}

Hubungan Lama Latihan dengan Daya Ledak Tungkai

\begin{tabular}{|c|c|c|c|c|c|c|c|c|}
\hline \multirow{3}{*}{ Lama Latihan } & \multicolumn{6}{|c|}{ Daya Ledak Tungkai } & \multirow{3}{*}{$\begin{array}{l}P \\
\text { Valu } \\
e\end{array}$} & \multirow{3}{*}{ OR $(95 \% C I)$} \\
\hline & \multicolumn{2}{|c|}{ Normal } & \multicolumn{2}{|c|}{$\begin{array}{l}\text { Di atas rata- } \\
\text { rata }\end{array}$} & \multicolumn{2}{|c|}{ Jumlah } & & \\
\hline & $\mathrm{n}$ & $\%$ & $\mathrm{n}$ & $\%$ & $\mathrm{n}$ & $\%$ & & \\
\hline 1-5 tahun & 35 & 68,6 & 16 & 31,4 & 51 & 100 & & \\
\hline$>6$ tahun & 10 & 22,7 & 34 & 77,3 & 44 & 100 & & 7,438 (2,963- \\
\hline Total & 45 & 100 & 50 & 100 & 95 & 100 & & $10,009)$ \\
\hline
\end{tabular}

Tabel 4.5 menjelaskan bahwa dari 51 responden yang baru menjalani latihan $<5$ tahun sebanyak 68,6\% memiliki daya ledak tungkai normal dan sebanyak 31,4\% responden memiliki daya ledak tungkai di atas rata, tabel 4.5 juga menjelaskan bahwa dari 44 responden yang sudah mengikuti latihan $>6$ tahun sebanyak 77,3\% memiliki daya ledak tungkai diatas rata-rata dan sebanyak $22,7 \%$ responden memiliki daya ledak tungkai normal.

Hasil uji statistik disimpulkan bahwa ada hubungan antara lama latihan terhadap daya ledak tungkai atlet taekwondo Kota Cimahi dengan hasil nilai pvalue $=0,000<\alpha$ $(\alpha=0,05)$. Dari hasil uji statistik diperoleh pula nilai $\mathrm{OR}=7,438$ dan nilai $95 \% \mathrm{Cl}=2,963$ - 
18.669, yang berarti pada responden yang baru berlatih 1-5 tahun mempunyai risiko 7,4 kali memiliki daya ledak otot tungkai normal dibanding dengan responden yang sudah berlatih selama $>6$ tahun

\section{Pembahasan}

\section{Gambaran Hubungan Umur Dengan Daya Ledak Tungkai}

Berdasarkan hasil olah data penelitian menunjukkan dari 55 responden yang berumur 12- 16 tahun sebanyak 58,2\% memiliki daya ledak tungkai normal dan sebanyak $41,8 \%$ memiliki daya ledak tungkai di atas rata-rata, tabel 4 juga menjelaskan bahwa dari 40 responden yang berumur 17-19 tahun sebanyak 67,5\% memiliki daya ledak tungkai diatas rata-rata dan sebanyak 32,5\% responden memiliki daya ledak tungkai normal. Hasil uji statistik chi-square disimpulkan bahwa ada hubungan antara umur terhadap daya ledak tungkai atlet taekwondo Kota Cimahi dengan hasil nilai pvalue $=0,014<\alpha$ $(\alpha=0,05)$. Dari hasil uji statistik diperoleh pula nilai $\mathrm{OR}=2,890$ dan nilai $95 \% \mathrm{Cl}=1,233$ 5,770, yang berarti pada responden yang berumur 17-19 tahun mempunyai risiko 2,89 kali memiliki daya ledak otot tungkai normal dibandingkan dengan responden yang berumur 12-16 tahun yang memiliki daya ledak otot tungkai di atas rata-rata

Seiring bertambahnya usia ada beberapa aspek yang membuat atlet anak lebih rentan terhadap cedera dikarenakan masih dalam masa pertumbuhan. Perbedaan jenis kelamin dapat mempengaruhi kekuatan dan kecepatan otot dengan adanya perbedaan hormon testosteron pada laki-laki dan wanita. Perbedaan terjadi sangat mencolok setelah seseorang mengalami pubertas, pada umur 18 tahun ke atas, laki-laki mempunyai kekuatan dua kali lebih besar daripada wanita (Nala, 2011).

\section{Gambaran hubungan Jenis Kelamin dengan Daya Ledak Tungkai}

Hasil Olah data penelitian menunjukkan dari 49 responden berjenis kelamin lakilaki sebanyak $49 \%$ memiliki daya ledak tungkai normal dan 6,1\% memiliki daya ledak tungkai di atas rata-rata, tabel 3 juga menunjukkan bahwa dari 46 responden yang berjenis kelamin perempuan sebanyak 54,3\% responden memiliki daya ledak tungkai di atas ratarata dan $45,7 \%$ memiliki daya ledak tungkai normal. Hasil uji statistik chi square disimpulkan bahwa tidak ada hubungan antara jenis kelamin terhadap daya ledak tungkai atlet taekwondo Kota Cimahi dengan hasil nilai pvalue $=0,905>\alpha(\alpha=0,05)$. Dari hasil uji statistik diperoleh pula nilai $\mathrm{OR}=1,143$ dan nilai $95 \% \mathrm{Cl}=0,510-2,560$

Menurut (Ismunandar, 2020) Penelitian epidemiologi terbaru, pada usia 5-17 tahun menunjukkan bahwa anak laki-laki lebih menyukai olahraga tim dan olahraga kontak dibandingkan anak perempuan. Anak laki-laki mengalami cedera dua kali lebih banyak dibandingkan anak perempuan. Anak laki-laki lebih sering mengalami cedera yang bersifat traumatis terutama berhubungan dengan muskuloskeletal. Di sisi lain, anak perempuan lebih sering mengalami cedera yang diakibatkan kegiatan olahraga yang berlebihan (overuse). Perbedaan faktor resiko dan jenis cedera ini berhubungan dengan pola gerakan olah raga yang dilakukan, kekuatan otot yang berbeda serta pemilihan jenis cabang olahraga (kontak/nonkontak; individual/tim). Olahraga dengan frekuensi 
melompat dan kontak fisik antar pemain yang tinggi merupakan olahraga dengan tingkat resiko terbesar untuk terjadinya cedera.

\section{Gambaran Hubungan Indeks Massa Tubuh dengan daya ledak Tungkai}

Hasil uji statistik chi square disimpulkan bahwa tidak ada hubungan antara IMT terhadap daya ledak tungkai atlet taekwondo Kota Cimahi dengan hasil nilai pvalue $=$ $0,604>\alpha(\alpha=0,05)$. Dari hasil uji statistik diperoleh pula nilai $\mathrm{OR}=0,722$ dan nilai $95 \%$ $\mathrm{Cl}=0,304-1,176$.

IMT dapat menjadi salah satu faktor risiko terjadinya cedera khususnya pada ligamen dikarenakan apabila seorang atlet memiliki IMT berlebih akan membuat tekanan pada ligamen betambah besar dan akan meningkatkan resiko cedera, dibandingkan dengan orang yang memiliki tinggi dan berat badan yang ideal. Obesitas juga dapat memperburuk kondisi sendi dan menyebabkan penurunan jaringan otot yang signifikan (Wiranata,et al. 2020)

\section{Gambaran Hubungan Lama Latihan dengan Daya Ledak Otot Tungkai}

Hasil penelitian menunjukkan bahwa mayoritas responden baru menjalani latihan taekwondo 1-5 tahun yaitu sebanyak 51 orang $(53,7 \%)$ dan sisanya yaitu sebanyak 44 orang sudah melakukan latihan > 6 tahun. Hasil penelitian ini menunjukkan bahwa sebagian besar atlet taekwondo kota Cimahi merupakan atlet-atlet baru di Kota Cimahi. Latihan rutin yang dijalani responden ini sangat berdampak positif terhadap kekuatan otot tubuh dan kondisi fisik atlet. Hal ini dikarenakan Latihan atau exercise adalah subkelompok aktifitas fisik berupa gerakan tubuh yang terencana, terstruktur dan repetitive (berulang). Latihan adalah proses melakukan kegiatan olahraga yang telah direncanakan secara sistematis dan terstruktur dalam jangka waktu yang lama untuk meningkatkan kemampuan gerak baik dari segi fisik, teknik, taktik, dan mental untuk menunjang keberhasilan siswa atau atlet dalam memperoleh prestasi olahraga yang maksimal (Langga and Supriyadi, 2017)

\section{Gambaran Daya Ledak Tungkai Responden}

Hasil penelitian menunjukkan bahwa mayoritas responden memiliki daya ledak tungkai dalam kategori normal yaitu sebanyak 45 orang $(47,4 \%), 32$ orang $(33,7 \%)$ memiliki daya ledak diatas rata-rata, 14 orang $(14,7 \%)$ memiliki daya ledak tungkai sangat tinggi dan sisanya yaitu 4 orang atlet $(4,2 \%)$ memiliki daya ledak tungkai yang luar biasa. kemampuan daya ledak tungkai dari setiap atlet yang diteliti berbeda-beda diantara atlet yang satu dengan atlet-atlet lainnya. Hal ini dapat dikarenakan kemampuan daya ledak tungkai seorang atlet dipengaruhi beberapa faktor seperti jenis kelamin, usia, berat badan, tinggi badan dan faktor-faktor lainnya.

Penelitian (Estevan et al., 2012) menunjukkan berat badan berdampak kuat pada kinerja tendangan dalam kaitannya dengan total response time (TT). Total response time (TT) yang dibutuhkan ketika menendang pada kelas heavyweight lebih lama dibandingkan kelas featherweight dan welterweight

Menurut (Wąsik and Shan, 2015), adanya target fisik berupa papan target maupun tanpa target yaitu ke udara akan mempengaruhi kecepatan tendangan dollyo chagi pada atlet taekwondo. Hal ini dapat dikarenakan target fisik mempengaruhi kondisi kerja atlet 
ketika menendang. Target fisik akan menjadi stimulus dalam memilih startegi yang tepat pada atlet untuk mengontrol motoriknya. Kedua latihan dengan target fisik akan mengerahkan daya ledak dalam menyeimbangkan kemampuan kontrol dari kekuatan otot dan kecepatan segmental. Atlet akan mempertimbangkan kecepatan untuk keakurasian/ ketepatan target. Atlet mengontrol akurasi target umumnya dengan mengurangi kecepatan dan rentang gerak, secara bersamaan mengerahkan kekuatan otot menendang dengan maksimal.

\section{Kesimpulan}

Berdasarkan hasil penelitian dan pembahasan penelitian tentang hubungan antara Indeks Masa Tubuh, jenis kelamin, umur dan lama latihan terhadap daya ledak otot tungkai pada atlet taekwondo Kota Cimahi. (1) Mayoritas atlet memiliki IMT normal yaitu 67,4\%, atlet berjenis kelamin lakilaki yaitu 51,6\%, atlet berumur 12-16 tahun yaitu $57,9 \%$, atlet yang menjalani latihan taekwondo selama 1-5 tahun yaitu 53,7\% dan atlet yang memiliki daya ledak tungkai normal yaitu 47,4\%. (2)Tidak ada hubungan antara IMT terhadap daya ledak tungkai atlet taekwondo Kota Cimahi dengan hasil nilai pvalue $=0,604>\alpha(\alpha=0,05) \mathrm{Cl}=1,233-5,770$, maka IMT bukan merupakan faktor risiko terjadinya cedera, (3) Tidak ada hubungan antara jenis kelamin terhadap daya ledak tungkai atlet taekwondo Kota Cimahi dengan hasil nilai pvalue $=0,905>\alpha(\alpha=0,05) \mathrm{Cl}$ $=1,233-5,770$, maka jenis kelamin bukan merupakan faktor risiko terjadinya cedera. (4) Ada hubungan antara umur terhadap daya ledak tungkai atlet taekwondo Kota Cimahi dengan hasil nilai pvalue $=0,023<\alpha(\alpha=0,05) \mathrm{Cl}=1,233-5,770$, maka usia merupakan faktor risiko terjadinya cedera. (5) Ada hubungan antara lama latihan terhadap daya ledak tungkai atlet taekwondo Kota Cimahi dengan hasil nilai pvalue $=0,000<\alpha(\alpha=0,05) \mathrm{Cl}$ =2,963-18.669, maka lama latihan merupakan faktor risiko terjadinya cedera. (6) Setiap komponen pembentuk daya ledak otot tungkai memiliki factor resiko cedera yang berbeda-beda, IMT yang lebih dari normal dapat meningkatkan resiko cedera karena adanya pembebanan yang berlebih pada jaringan Ketika aktifitas, umur pertumbuhan remaja memiliki factor resiko cedera yang tinggi karena terdapat lempeng pertumbuhan tulang yang terbuka dan dapat denga mudah terjadi cedera, laki-laki lebih berpotensi terkena cedera musculoskeletal karena adanya trauma/benturan keras sedangkan cedera wanita disebabkan oleh overuse, semakin lama seseorang mengikuti Latihan maka akan semakin baik pula fleksibilitas otot nya sehingga dapat meminimalisir terjadinya cedera 


\section{BIBLIOGRAFI}

Baihaqi, J. and Hariyanto, E. (2020) 'Studi Tentang Indeks Massa Tubuh Terhadap Kondisi Fisik Atlet Muaythai Pusat Pelatihan Kabupaten Malang', Sport Science and Health, 2(10), pp. 471-483. Google Scholar

Estevan, I. et al. (2012) 'Effect of olympic weight category on performance in the roundhouse kick to the head in taekwondo', Journal of Human Kinetics, 31(1), pp. 37-43. doi: 10.2478/v10078-012-0004-x. Google Scholar

Harun, H. and Xiong, S. J. (2010) 'The symmetry in kinematics between the dominant and non-dominant legs in taekwondo turning kick', Universiti Teknologi Malaysia Institutional Repository, (August), pp. 1-6. Google Scholar

Langga, Z. A. and Supriyadi (2017) 'Pengaruh Model Latihan Menggunakan Metode Praktik Distribusi Terhadap Keterampilan Dribble Anggota Ekstrakurikuler Bolabasket SMPN 18 Malang', Jurnal Kepelatihan Olahraga, 1(1), pp. 90-104. Google Scholar

Nala, I. G. N. (2011) Prinsip Pelatihan Fisik Olahraga. Bali: Udayana University Press. BALI: Udayana University Press : Denpasar, Bali., 2011. Google Scholar

Pasaribu, A. M. N. (2015) Tes dan Pengukuran OLahraga, Tes dan Pengukuran Olahraga. Google Scholar

Wahyuni, S. and Donie (2020) 'Vo2Max,Daya Ledak Otot Tungkai,Kelincahan Dan Kelentukan Untuk Kebutuhan Kondisi Fisik Atlet Taekwondo', Jurnal Patriot, 2(2), pp. 1-13. Google Scholar

Wąsik, J. and Shan, G. (2015) 'Target effect on the kinematics of Taekwondo Roundhouse Kick - Is the presence of a physical target a stimulus, influencing muscle-power generation?', Acta of Bioengineering and Biomechanics, 17(4), pp. 115-120. doi: 10.5277/ABB-00229-2014-02. Google Scholar

Widhinata, I. (2010) 'DAN TANPA STRETCHING TERHADAP TINGGI JUMPING SMASH'. Google Scholar

Wiranata, P., Handoyo, H. R. and Kurniawan, P. M. (2020) 'Body Mass Index And Age With Ankle Injury In Basketball Player', Journal Widya Medika Junior, 2(1), pp. 65-74. doi: 10.33508/jwmj.v2i1.2337. Google Scholar

First publication right:

Jurnal Syntax Fusion: Jurnal Nasional Indonesia

This article is licensed under:

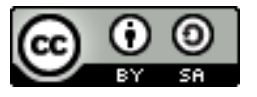

